\title{
Resources of Music
}

New

\section{Living School Music \\ William Salaman}

The author, from his wide teaching experience, provides a guide covering the main areas of current music teaching; a book which is concerned with living the life of a music.teacher and working to create an environment within the classroom for the music itself to live.

Hard covers £8.25 net Paperback £3.95 net

For publication in late 1984

\section{Wind Bands and Brass Bands in} School and Music Centre

Kevin Thompson

Hard covers about $£ 9.50$ net Paperback about $£ 4.95$ net

\section{Cambridge Assignments in Music}

\section{Roy Bennett}

A balanced mixture of clear exposition and related work and assignments, the books in this very successful series have established themselves as key material for candidates for first examinations.

\section{Form and Design}

\section{Instruments of the Orchestra History of Music}

New

\section{General Musicianship}

Paperback about $£ 1.95$ net Cassette about $£ 8.25+$ VAT in UK

Two new titles for publication in late 1984

\section{Keyboard Instruments}

\section{Score Reading}

Inspection copies from Katie Eaglestone, Cambridge University Press, The Edinburgh Building, Shaftesbury Road, Cambridge CB2 2RU

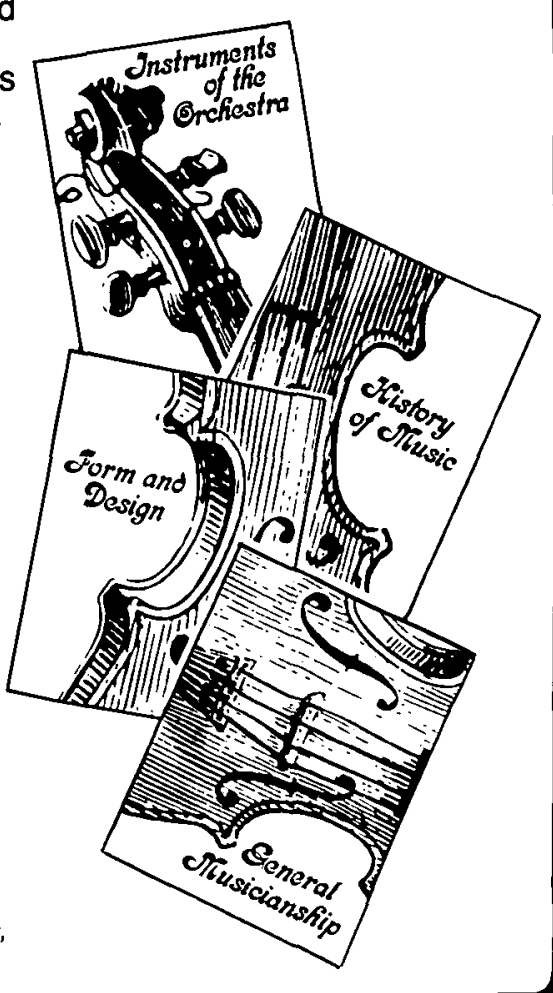

\section{CAMBRIDGE UNIVERSITY PRESS}




\title{
A Basis for Music Education Professor Keith Swanwick
}

\author{
'We are indebted to Professor \\ Swanwick for his clear and practical \\ approach to basic issues in music \\ education' \\ Music Teacher \\ $\therefore$ written with clarity, vigour \\ and not without wit and humour' \\ The Australian Journal of Music Education
}

There is currently a lack of a strong conceptual framework for music education. This gives rise to loss of direction in teaching, and music educators are often unable to negotiate their way through the complexities of educational values, systems and professional demands. Of all the arts curriculum areas, music is in the greatest need of a rationale that withstands examination and underpins the fabric of practice. A Basis for Music Education represents an attempt to deal with the central and crucial issues of music education.

Professor Keith Swanwick is the Head of the Music Department at the University of London Institute of Education.

Contents: The meaningfulness of Music; The Feelingfulness of Music; The Parameters of Music Education; The Model in Action; 'Creativity', 'Contemporary' and 'Integration'; Music, Society and the Individual; Bibliograph; Index.

\begin{tabular}{lllll}
\hline 1979 & 132 pages & 8447024 & 0856331805 & $\mathbf{E 6 . 4 5}$
\end{tabular}

To order copies of the above title, please write to The Promotions Department, NFER-NELSON, Darville House, 2 Oxford Road East, Windsor, Berkshire, SL4 1DF, quoting the title and the order number and enclosing cash with order (unless you have an account with us).

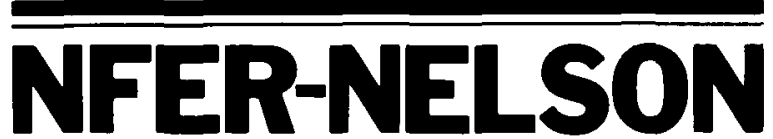




\section{Notes for Contributors}

1a. All contributions ( 3 copies) and correspondence should be sent to either Editor: Professor John Paynter, Department of Music, University of York, Heslington, York YO1 5DD, or Professor Keith Swanwick, Department of Music, University of London Institute of Education, 20 Bedford Way, London $\mathrm{WC}_{1} \mathrm{H} \circ \mathrm{OLL}$.

1 b. All material for review, and text of reviews, should be sent to the Review Editor, Andrew Peggie, 5 Poplar Walk, Herne Hill, London SE24 oBX. Only one copy of the review need be sent.

2a. Articles should be normally within the range 3,00010,000 words, although longer or shorter articles may be accepted by arrangement with the Editors.

$2 \mathbf{b}$. Reviews and surveys will have their lengths prescribed by the Review Editor, at the time of commissioning.

3. Contributions (articles, review articles, reviews) should be clearly typed on one side of the paper only (preferably A 4 size). All material should be typed double spaced with generous margins. In addition to the three copies submitted (one, in the case of reviews), contributors should keep a further copy of the typescript for correcting proofs.

4. Articles should be accompanied by a summary of approximately 100 words, together with information about the position/s held by the author/s and giving full details of any acknowledgements. In long articles, subheadings are encouraged.

5. All quotations and references should be identified in the text by author and date to link with the full references listed alphabetically at the end of the article. E.g. in the text, bracketed thus: (Self, 1976); in the alphabetical reference list thus: Self, G. 1976. Make a New Sound. London, Universal Edition.

6. The full list of references should be typed, double spaced, on a separate sheet of paper at the end of the article. They must include the names and initials of all the authors cited (arranged in alphabetical order of the authors' surnames) and followed by (in the case of books) the date of publication, the title (underscored), the place of publication and the name of the publisher, or (in the case of articles cited) the date of publication, the full title of the article (not underscored), the name of the journal in which the article appeared (underscored), the volume number, issue number, and page number/s. Reference to an article which appears in a book should be made thus: the author's name, date of publication (in brackets), title of the article (in inverted commas), 'In' followed by author/s name(s) and title of the book (underscored), place of publication and name of publisher. E.g. Pollard, M. (1978). 'Folk Music in junior and middle schools'. In Leach, R. and Palmer, R., Folk Music in School. Cambridge, Cambridge University Press.
7. Notes other than bibliographical references should be given only when absolutely essential. These should be referred to in numerical order throughout the text and the number shown as superscript. The notes should then appear on a separate sheet of paper at the end of the article.

8. All necessary illustrations should accompany the typescript but should not be inserted in the text. All photographs, drawings and diagrams should be referred to as "figures" and should be numbered consecutively in the order in which they are referred to in the text. A list of captions should be provided on a separate sheet. Photographs should be well-contrasted prints with glossy finish (preferably $10^{\prime \prime} \times 8^{\prime \prime}$ ), if possible mounted on thin card. Each should have, lightly written on the back with felt-tipped pen, the author's name and the figure number. Authors to whom first-class photographic facilities are not available are encouraged to send both marked contact prints and the negatives under registered cover. Drawings and diagrams should be done in indian ink on strong paper, white card, or good-quality tracing paper.

9. A cassette tape of 40 minutes maximum duration will be available once a year, normally accompanying every third issue of the British Journal of Music Education. Contributors may wish to avail themselves of this opportunity to present musical examples, even if these refer to articles which have appeared in either of the two previous issues. Recorded material must be submitted in its final edited form (on cassette or open-reel). To facilitate transfer to the published tape, it will be helpful if contributors could ensure that the master tapes are of the highest possible quality. Individual items on the tape should be identified by aural cues which will correspond with a typewritten list. The author's name should be clearly written on each tape and tape box.

10. Proofs of all articles accepted will be sent to authors for correction of typographical errors only. Failure to return proofs within the specified deadline may lead to the Editors sending their own corrected proofs to the printer without further reference to the author.

11. Twenty-five offprints will be supplied free of charge to authors on publication of a paper. These must be shared in case of joint authorship. Additional offprints may be purchased if ordered at proof stage.

12. Authors will be requested to assign their copyright to Cambridge University Press to protect their rights and those of the Journal. Authors are responsible for obtaining any necessary permissions to quote copyright material in their article. 


\section{BRITISH JOURNAL OF MUSIC EDUCATION \\ Volume I Number I, March 1984}

\section{CONTENTS}

Biographical Notes on Contributors $\quad 1$

Editorial 3

Tom Gamble: Imagination and Understanding in the Music Curriculum 7

Brian Loane: On 'Listening' in Music Education $\quad 27$

Caroline Gebbie, David Elliott, Clare Morris: First Year in Teaching 37

1. Towards a Creative Approach in Scotland - a Personal Experience 39

2. My First Year of Teaching 49

3. Probation 53

Pamela O'Gorman: The First 21 Years in the Life of the Jamaica School of Music $1961 / 62$ to $1982 / 83$

BOOK REVIEWS

(c) Cambridge University Press 1984

Cambridge University Press

The Pitt Building, Trumpington Street, Cambridge CB2 1RP

32 East 57th Street, New York, NY 10022

Printed in Great Britain at the University Press, Cambridge 